\title{
Study of blood component therapy in obstetrics
}

\author{
Nidhi Pancholi* \\ Department of Obstetrics and Gynecology, B. J. Medical College, Ahmedabad, Gujarat, India
}

Received: 14 April 2019

Accepted: 23 April 2019

\section{*Correspondence:}

Dr. Nidhi Pancholi,

E-mail: nidhi_pancholi@ymail.com

Copyright: ( $)$ the author(s), publisher and licensee Medip Academy. This is an open-access article distributed under the terms of the Creative Commons Attribution Non-Commercial License, which permits unrestricted non-commercial use, distribution, and reproduction in any medium, provided the original work is properly cited.

\section{ABSTRACT}

Background: Blood transfusion is a life saving measure. Various pregnancy complications and disorders of labor present as risk factors for extra blood loss during pregnancy and cause severe hemodynamic instability. This along with complications due to abortion (spontaneous or induced) and ruptured ectopic pregnancy show up as conditions needing transfusion in the day-to-day practice of obstetrics. In a country like India, limited and fixed resources of blood, forces us to titrate the use of blood and its components. Normally, blood loss during birth is well-tolerated because of changes during pregnancy.

Methods: This is a retrospective observational study done at tertiary care hospital. This study is based on study of indoor patients admitted during one year duration. Detailed history and all necessary investigations were carried out. Details regarding blood transfusion were taken indication of blood transfusion, number and type of unit transfused, number of patients given blood components, indications where single unit was transfused. Analysis of the data was done.

Results: Anemia followed by antepartum hemorrhage followed by postpartum hemorrhage was the major cause for blood and blood product transfusion. Approximately $60 \%$ patients required two units of PCV (Packed Cell Volume) transfusion. Anemia in pregnancy was the major cause of single unit PCV transfusion.

Conclusions: A proper knowledge for blood and blood product transfusion is needed to make it available for people who are actually in need and also to decrease the economic burden. Measures to prevent anemia should be implemented. Active management of third stage of labour (AMTSL) should be done to avoid postpartum hemorrhage. Single unit transfusion should be avoided.

Keywords: Active management of third stage of labour, Cryoprecipitate, Massive transfusion, Packed cell volume, Single unit transfusion

\section{INTRODUCTION}

Blood transfusion is a life saving measure. Normally, blood loss during birth is well-tolerated because of changes during pregnancy. In general, $<15 \%$ loss results in minimal symptoms; $15-30 \%$ causes tachycardia; 30$40 \%$ shock; $>40 \%$ loss leads to severe shock. With underlying diseases, even with $<30-40 \%$ loss, blood is required. ${ }^{1}$ The risk of mortality increases significantly in otherwise stable patients when the hemoglobin $(\mathrm{Hb})$ falls to $3.5-4 \mathrm{~g} / \mathrm{dL}$, but in cases with ischemic heart disease with $7 \mathrm{~g} / \mathrm{dL} .^{2}$ So, obstetric hemorrhage is a major cause of perinatal and maternal mortality, about 25-30\% maternal deaths due to hemorrhage. ${ }^{3}$ Various pregnancy complications and disorders of labor present as risk factors for extra blood loss during pregnancy and cause severe hemodynamic instability. This along with complications due to abortion (spontaneous or induced) and ruptured ectopic pregnancy show up as conditions needing transfusion in the day-to-day practice of obstetrics. ${ }^{4}$ Over the last 30 years there has been a general trend towards a reduced use of blood transfusion in 
obstetric and gynecological practice. The reason for this trend being risk of transfusion especially blood borne diseases and better pharmacological, surgical and mechanical innovations to reduce blood loss and iron supplementation for high risk people. In a country like India, limited and fixed resources of blood, forces us to titrate the use of blood and its components.

\section{METHODS}

This study was conducted to know the various indications of blood transfusion (blood and blood products) in department of obstetrics. This study is a retrospective observational study done on patients who were admitted in obstetric department for the duration of one year from February 2012 to January 2013 in a tertiary care institute. Numbers of transfusions were noted out of all indoor patients irrespective of the department of our hospital. There were 3000 indoor obstetric patients.

\section{Inclusion criteria}

- Patients diagnosed with moderate to severe anemia with clinical indication of blood transfusion

- Patient diagnosed with hemorrhage in early pregnancy with clinical indication of blood transfusion

- Patient diagnosed with antepartum hemorrhage with clinical indication of blood transfusion

- Patient diagnosed with intrapartum hemorrhage with clinical indication of blood transfusion

- Patient diagnosed with postpartum hemorrhage with clinical indication of blood transfusion.

\section{Exclusion criteria}

- Patient with mild anemia

- Patient diagnosed with hemorrhage in early pregnancy without clinical indication of blood transfusion

- Patient diagnosed with antepartum hemorrhage without clinical indication of blood transfusion

- Patient diagnosed with intrapartum hemorrhage without clinical indication of blood transfusion

- Patient diagnosed with postpartum hemorrhage without clinical indication of blood transfusion.

Of these 140 patients were given blood transfusion. A detailed history of socio-economic class, obstetric history, menstrual history and number of antenatal visits was taken and thorough clinical examination was done. On admission, routine investigations like hemoglobin, blood group, platelet count, bleeding time, clotting time, prothrombin time, S. Fibrinogen, D-Dimer as well as ultrasound was done. The indications of blood transfusion were studied in detail and decided whether it was actually needed or can be avoided. Details about blood transfusion like.

- The indication of blood transfusion
- Number and type of unit transfused

- Number of patients given blood components

- Indications where single unit was transfused.

\section{RESULTS}

In our study the indications were pregnancy with anemia 28.57\%; antepartum hemorrhage (abruptio placentae/ placenta previa) $23.57 \%$; postpartum hemorrhage $21.42 \%$; ectopic pregnancy $10.0 \%$; abortion $10.0 \%$; LSCS and Instrumental delivery $6.42 \%$.

Table 1: Indications of blood transfusion in obstetrics.

\begin{tabular}{|lll|}
\hline $\begin{array}{l}\text { Indications for blood } \\
\text { transfusion }\end{array}$ & $\begin{array}{l}\text { No. of } \\
\text { patients }\end{array}$ & Percentage \\
\hline Pregnancy with anemia & 40 & 28.57 \\
\hline $\begin{array}{l}\text { Antepartum hemorrhage } \\
\text { (Abruptio placentae/ } \\
\text { placenta previa) }\end{array}$ & 33 & 23.57 \\
\hline Postpartum hemorrhage & 30 & 21.42 \\
\hline Abortion & 14 & 10.0 \\
\hline Ectopic pregnancy & 14 & 10.0 \\
\hline $\begin{array}{l}\text { LSCS and instrumental } \\
\text { delivery }\end{array}$ & 9 & 6.42 \\
\hline
\end{tabular}

In this study $18.57 \%$ of transfused patients received 1 unit; $42.85 \%$ of patients received 2 units, $12.85 \%$ received 3 units and $12.14 \%$ received 4 units; $13.57 \%$ received greater than or equal to 5 units of packed red blood cells.

Table 2: No. of units of PCV transfused per patient.

\begin{tabular}{|lll|}
\hline No. of units & No. of patients & Percentage \\
\hline Single & 26 & 18.57 \\
\hline 2 & 60 & 42.85 \\
\hline 3 & 18 & 12.85 \\
\hline 4 & 17 & 12.14 \\
\hline 5 or more & 19 & 13.57 \\
\hline
\end{tabular}

Table 3: Analysis of single unit transfusion.

\begin{tabular}{|lll|}
\hline Indication & $\begin{array}{l}\text { No. of } \\
\text { patients }\end{array}$ & Percentage \\
\hline Pregnancy with anemia & 16 & 61.53 \\
\hline $\begin{array}{l}\text { LSCS or instrumental } \\
\text { delivery }\end{array}$ & 5 & 19.23 \\
\hline Abruptio placentae & - & - \\
\hline Ectopic pregnancy & - & - \\
\hline Placenta previa & - & - \\
\hline Abortion & 4 & 15.38 \\
\hline Postpartum hemorrhage & 1 & 3.84 \\
\hline Total & $\mathbf{2 6}$ & \\
\hline
\end{tabular}

The indications for single unit transfusion were pregnancy with anemia $(61.53 \%)$, LSCS or instrumental 
delivery (19.24\%), abortion (15.38\%), postpartum hemorrhage $(3.84 \%)$.

Table 4: Use of different components.

\begin{tabular}{|llc|}
\hline Type of blood component & No. of units & Percentage \\
\hline PCV & 279 & 46.6 \\
\hline FFP & 128 & 21.4 \\
\hline PRC & 142 & 23.7 \\
\hline Cryoprecipitate & 49 & 8.1 \\
\hline
\end{tabular}

It was observed in our study that $21.4 \%$ patients were transfused with fresh frozen plasma, $46.6 \%$ patients were transfused with packed cell volume transfusion, and $23.7 \%$ patents were transfused with platelet transfusion and cryoprecipitate transfusion $(8.1 \%)$.

\section{DISCUSSION}

Preeclampsia In our study (Table 1) the indications were pregnancy with anemia $28.57 \%$; antepartum hemorrhage (abruptio placentae/ placenta previa) $23.57 \%$; postpartum hemorrhage $21.42 \%$; ectopic pregnancy $10.0 \%$; abortion $10.0 \%$; operative delivery $6.42 \%$. Major indications for transfusion in a retrospective review of 7731 mothers by Kamani et al, found were uterine atony, $27 \%$; retained placenta, 17\%; trauma, $17 \%$, placenta previa, $7 \%$; and abruptio placentae, $5 \%$. In $12 \%$ of patients transfusions were done because of anemia. 5 Measures to prevent anemia must be promoted. Active management of third stage of labor can prevent the number of anticipated blood transfusion. ${ }^{6,7}$

In this study (Table 2), $18.57 \%$ of transfused patients received 1 unit; $42.85 \%$ of patients received 2 units, $12.85 \%$ received 3 units and $12.14 \%$ received 4 units; $13.57 \%$ received greater than or equal to 5 units of packed red blood cells. According to a study by Kamani AA, $5 \%$ of transfused patients received 1 unit; $52 \%$ of patients received 2 units, $19 \%$ received 3 units and $24 \%$ received greater than or equal to 4 units of packed red blood cells. ${ }^{5}$

The indications for single unit transfusion (Table 3) were pregnancy with anemia (61.53\%), LSCS or instrumental delivery $(19.24 \%)$, abortion $(15.38 \%)$, postpartum hemorrhage $(3.84 \%)$. Currently there are 30 major blood group systems and more than 308 red cell antigens. ${ }^{8}$ However, during pre-transfusion testing blood bank tests for only $\mathrm{ABO}$ and $\mathrm{Rh}(\mathrm{D})$ antigens, thus transfusion poses a risk of alloimmunization to other blood group antigens. There are also several other risks like transmission of infections, different types of transfusion reactions etc. ${ }^{9}$ Therefore clinicians must prevent single unit transfusion in adult patients which can raise $\mathrm{Hb}$ only by $1-1.5 \mathrm{~g} / \mathrm{dL} .^{10}$ WHO strongly discourages single unit transfusion. ${ }^{11}$ The practice of single unit transfusion is largely avoidable. ${ }^{12}$
It was observed in our study (Table 4 ) that $21.4 \%$ patients were transfused with fresh frozen plasma, $46.6 \%$ patients were transfused with packed cell volume transfusion, $23.7 \%$ patents were transfused with platelet transfusion and cryoprecipitate transfusion $(8.1 \%)$. It was observed in a study by Bangal VB et al, that $46.62 \%$ patients were transfused with fresh frozen plasma, $45.81 \%$ patients were transfused with packed cell volume transfusion, $4.02 \%$ patents were transfused with platelet transfusion and cryoprecipitate transfusion $(0.33 \%){ }^{13}$ In another study by Chawla et al, it was observed that $66 \%$ patients were transfused with fresh frozen plasma, $79 \%$ patients were transfused with packed cell volume transfusion, $15 \%$ patents were transfused with platelet transfusion. ${ }^{4}$ The Ten Commandments for the transfusion practice in medicine state that transfusion should only be used when the benefits outweigh the risks and there are no appropriate alternatives, and laboratory tests should not be the sole deciding factor for transfusion. ${ }^{14}$ The guidelines for blood transfusion to obstetrics (Ob)/gynecology (Gy) patients are available. ${ }^{11,15}$ Blood transfusion may be a lifesaving procedure but it is not without risk. Recipients may rarely develop transfusiontransmitted infections or suffer immunological sequelae such as red cell alloimmunisation. The major risk is of a patient receiving incorrect blood component. Hence blood transfusion must be done only after due diligence to the situation and adhering to guidelines. All possible policies should be looked into for preventing blood transfusion in patients to reduce the risk of transfusion. Promoting component therapy not only brings down the requirement of Whole Blood, but also ensures optimum use of blood.

\section{CONCLUSION}

Incidence of blood transfusion in obstetric patients is high. Obstetric patients are major consumer of blood bank services.

A proper knowledge for blood and blood product transfusion is needed to make it available for people who are actually in need and also to decrease the economic burden. The appropriateness of utilization of blood and blood products lies with the physicians' compliance with blood transfusion guidelines. Anemia followed by obstetric hemorrhage still persists to be a major cause for blood and blood product transfusion. Measures to prevent anemia should be implemented. Obstetric hemorrhage is an emergency situation and cannot always be avoided or prevented. AMTSL should be done to avoid postpartum hemorrhage. Single unit transfusion should be avoided.

\section{ACKNOWLEDGMENTS}

Authors would like to thank the patients who agreed to participate in this study and the staff who helped recruits patients. 
Funding: No funding sources

Conflict of interest: None declared

Ethical approval: Not required

\section{REFERENCES}

1. Chhabra NS, Namgyal A. Rationale use of blood and its components in obstetric-gynecological practice. J Mahatma Gandhi Inst Med Sci. 2014;19(2):93-9.

2. Bonnar J. Massive obstetric hemorrhage. Baillieres Best Pract Res Clin Obstet Gynaecol. 2000;14:1-18.

3. The World Health Report 2005. Make every mother and Child count. Available at; http://www.who.int/whr/2005/en.

4. Chawla S, Bal MH, Vardhan BS, Jose CT, Sahoo I. Blood transfusion practices in obstetrics: our experience. J Obstet Gynecol India. 2018;68(3):2047.

5. Kamani AA, McMorland GH, Wadsworth LD. Utilization of red blood cell transfusion in an obstetric setting. Am J Obstet Gynecol. 1988;159(5):1177-81.

6. McCormick ML, Sanghvi HC, Kinzie B, McIntosh N. Preventing postpartum hemorrhage in low-resource settings. Int $\mathrm{J}$ Gynecol Obstet. 2002;77(3):267-75.

7. Prendiville WJ, Elbourne DR, Stirrat GM. Active versus physiological management of third stage of labour, Cochrane Library. Oxford Update Software. 2001;3.

8. Storry JR, Castilho L, Daniels G, Flegel WA, Garratty G, Francis CL, et al. International society of blood transfusion working party on red cell immunogenetics and blood group terminologies: Berlin report. Vox Sang. 2011;101:77-82.

9. World Health Organization Publication N. SEA/HLM/311. Promoting and practicing rational use of blood. In: Strategies for safe blood transfusion. WHO Publication, New Delhi. 1998:2431.

10. Gupte SC, Patel PN. Blood transfusion practice in obstetrics and gynecology: impact of educational programs to create awareness for judicious use of blood components. Indian J Hematol Blood Transfus. 2014;30(3):175-9.

11. WHO Blood Safety Handbook. The clinical use of blood. WHO/BTS/99.3, Geneva. 2001:122-34.

12. Vachhani JH, Joshi JR, Bhanvadia VM. Rational use of blood: a study report on single unit transfusion. Indian J Hematol Blood Transfus. 2008;24(2):69-71.

13. Bangal VB, Gavhane SP, Aher KH, Bhavsar DK, Verma PR, Gagare SD. Pattern of utilization of blood and blood components in obstetrics at tertiary care hospital. Int J Reprod Contracept Obstet Gynecol. 2017;6:4671-6.

14. Derek N. Transfusion Ten commandments. In: Handbook of transfusion medicine. $5^{\text {th }}$ ed. Norwich: TSO Publishers; 2013:1-3.

15. Royal College of Obstetricians and Gynaecologists Blood transfusion in obstetrics. Green Top Guidel. 2008;47:1-10.

Cite this article as: Pancholi N. Study of blood component therapy in obstetrics. Int J Reprod Contracept Obstet Gynecol 2019;8:2155-8. 